\title{
Towards a Political Economy of Communication in Development?
}

\author{
Florencia Enghel
}

\begin{abstract}
In the development communication equation, whether more theoretical, empirical and analytical attention is given to 'development' or to 'communication' makes a difference: where the emphasis is on development, it is at the expense of communication. Since communication and media arguably play an increasingly pervasive role in the everyday life of citizens and in the politics, economies and governance of most societies, the characteristics and role of specific forms of applied communication strategies in the context of the neoliberal project merit critical scrutiny. Given a complex global scenario, what can a political economy approach bring into an agenda for the future of development communication as a field of study, a practice and an institutional project? This article outlines ways in which a focus on political economy dimensions may contribute to understanding the obstacles and limits to a transformative practice of international development communication.
\end{abstract}

Keywords: development communication, political economy, practice, neoliberalism

\section{Introduction}

That strategic communication interventions can and must play a positive role in the production of social change is the central tenet of development communication, understood here as a subset of both communication and media studies and international development studies, as well as a practical and institutional component of international development cooperation ${ }^{1}$. At present, the research and theorization of development communication take place under challenging contextual conditions: increasing pressure towards demonstrating and communicating aid results (da Costa, 2009; Lennie and Tacchi, 2013), unstable development aid budgets ${ }^{2}$ (Evans, 2013), and a concern with strengthening and institutionalizing the practice and evaluation of development communication within bilateral and multilateral agencies voiced by practitioners and academics alike (UNICEF \& CI, 2012; McAnany, 2012; Lennie \& Tacchi, 2013).

While other terms are used to describe the field - communication for development (e.g. Servaes, 2007; Lennie \& Tacchi, 2013), communication for social change (e.g. Gumucio-Dagron \& Tufte, 2006) and communication for development and social change (e.g. McAnany, 2012) - and which one is more appropriate remains a matter of debate (see e.g. Wilkins, 2009; Enghel 2013), retaining development communication ${ }^{3}$ as a key concept is useful for the purposes of this article in order to consider the relationship between its two component elements. This is because whether more theoretical, em- 
pirical and analytical attention is given to 'development' or to 'communication' does in fact make a difference: where the emphasis is on development, it is at the expense of communication (Quebral, 1988 quoted in Manyozo; Enghel, 2014). It may actually be because of the subsidiary role of communication in development that over time research and theorization within the field have not led to the formulation and implementation of policy frameworks at the national or international level despite the normative efforts of scholars, unlike other academic fields which clearly involve a dimension of public policy making, e.g. education ${ }^{4}$. In the absence of specific policies, the practice of international development communication is largely unregulated, and issues of accountability (and ethics) for its planning, implementation and funding remain understudied (Enghel, 2014).

But development communication is not only a field of study. It is also a (more or less) professional practice, and an institutional project ${ }^{5}$ with a geopolitical underpinning and a specific governance structure, such that the citizens of the countries intervened are subject to the rules for implementation imposed by the intervening countries "even though the rule-makers are not accountable to those whom they govern" (Fraser, 2008: 65; Enghel, 2014). The political economy of these three dimensions of development communication - study, practice and project - remains understudied in empirical research. Given this scenario, the purpose of this article is to outline ways in which a political economy of communication in development may contribute to understanding the limits to the practice of international development communication as a transformative endeavor. Understanding those limits is a necessary step towards restating the potential of strategic communication to redress unjust global conditions under neoliberal conditions. I situate my argument in the context of a global scenario arguably under transformation, in which communication and media have come to play distinct roles.

\section{The Game and its Rules}

The Organization for Economic Cooperation and Development (OECD), the international economic organization that "brings around its table 40 countries that account for $80 \%$ of world trade and investment" , sets the rules for the monitoring and evaluation of international development cooperation - and therefore institutionally driven development communication allocations - with a focus on results-based management. While according to the Organization's own data most communication departments within development cooperation agencies focus their investment on educating donor publics about development or convincing them that aid is working (Zimmerman, 2007 quoted in da Costa, 2009), which proportion of those agencies' allocations is directed to development communication intervention is unknown, because aid statistics collated by OECD do not detail specific expenditures. As a consequence, it is not possible to analyze trends in development communication spending, identify continuity and change in terms of top funders and recipients, distinguish problems and solutions favored and disregarded over time, or compare with spending allocated to public relations or other forms of "communicating development results' ${ }^{7}$. The specifics of how funds aimed at development communication intervention are actually spent are not known either, making it difficult to plan and cost future actions (Manyozo, 2014) ${ }^{8}$.

The lack of detail is not restricted to allocations or expenditures. A review of five studies of existing development communication research published in English between 
2003 and $2013^{9}$ (Enghel, 2014) reveals a wider-encompassing need for rigorous and comprehensive inquiries in order to inform subsequent interventions within large-scale processes of international development cooperation. The most recent among those five studies, Skuse et al (2013), specifically looked into development communication interventions in fragile states at the request of the Australian Agency for International Development (AusAID). The study was published shortly before the Australian government announced a drastic reduction of the country's foreign aid budget in January 2014 and the demotion of AusAID, which was merged with the Department of Foreign Affairs and Trade (Davies, 2013), and may have thus fallen into deaf years once the organization that commissioned it became defunct. This example calls our attention to the often-unattended structural conditions that shape development communication.

\section{Development Communication as a Three-dimensional Object of Analysis}

One reason for conceptualizing development communication as a field of study, as a practice and as a project is that this three-dimensional perspective brings into view the specifics of each area of activity as well as the inter-spaces in which they interact. Rendering visible those spaces of interaction is relevant in that, while the three dimensions influence each other, the relative power of each on the others differs. A recently completed qualitative study of development communication intervention in the context of international development cooperation suggests that the institutional project rules and the practice follows, calling for further empirical inquiry of development communication intervention as a process embedded in specific conditions that have an impact on its trajectory (Enghel, 2014). A well-known differential in terms of power is that development has generally been the stronger factor in the 'development communication' equation and received greater attention than communication (Quebral, 1988 quoted in Manyozo, 2012; Waisbord, 2008).

For the most part, in development communication scholarly work published between 2003 and 2013 (Enghel, 2014), communication and media initiatives are understood to support development intervention, in line with what appears to take place in practice. In correlation with the fact that development is understood as the driving factor and communication is considered subsidiary, more attention is given to development theory, and less to theorizing the role played by communication and media in the project of managing international development cooperation under neoliberal conditions. According to the above-mentioned studies of existing inquiries, empirical research within the field has been primarily quantitative, seeking to measure media effects and to provide evidence of success. In line with an orientation towards outcomes and a disregard of processes, minimal attention has been directed towards the contextual and institutional conditions that come into play in the concrete practice of intervention. Those conditions include, but are not limited to, procedures and rationales for budget allocations, rules for disbursement and reporting, and tensions and duplicity between doing good and communicating do-gooding (Enghel, 2014).

Across the three dimensions -study, practice and project- communication tends to be conceptualized both as a powerful tool that can be administered to lead to ever-positive results in the 'quest' for social change, however defined, and as a neutral tool that can 
be used to carry out similar functions in disparate contexts. Alternatively, a political economy approach to understanding the role of communication in development would direct attention to it as a civic right and a capability socially distributed in unequal ways and characterized by an ambiguous potential (Enghel, 2014). Outlining the specifics of each of the three dimensions of international development communication from this perspective brings into view certain types of knowledge that are not readily available and could be addressed in future research agendas.

The field of study has traditionally been concerned with the role and value of strategic communication and media-driven initiatives or projects in the promotion of social change in the context of international development cooperation intervention (see e.g. Servaes, 2005; Kim, 2005; Roman, 2005; Gumucio-Dagron and Tufte, 2006; Manyozo, 2006; Inagaki, 2007; Shah, 2007 and 2008; Wilkins, 2008; Greiner and Singhal, 2009; Kincaid and Figueroa, 2009; McPhail, 2009; Dutta, 2011; and McAnany, 2012 for a variety of accounts of that tradition). One example of what we do not know about the field of study in recent years is the extent to which funding sources for research have shifted from being unconstrained to being allocated by bilateral or multilateral agencies responsible for international development cooperation in line with their agendas (Shah, 2007), and the potential impact of changes in the sources of funding on independent inquiries.

The professional practice is concerned with the planning and implementation of communication and media initiatives aimed at achieving a variety of sociopolitical goals, premised on the assumption that strategic communicational action can cause more or less distinct effects. The scale, focus, means and ends of development communication initiatives may vary across a wide range (see Gumucio-Dagron and Tufte, 2006 for examples; see also Wilkins, 2008). While it is common knowledge that practitioners work 'in the field', little is known about the characteristics of their employment. Internal development communication units exist at present in some multilateral agencies, e.g. UNICEF and $\mathrm{FAO}^{10}$ within the United Nations system, and over the years a number of non-governmental organizations in different parts of the world have specialized (or at least focused primarily) in the planning and implementation of development communication programs (e.g. Soul City in South Africa, Femina in Tanzania, or Calandria in Perú; see Ramafoko et al, 2012, Tufte, 2014 and Alfaro, 2012 for discussions). However, at present implementation may be mainly subcontracted out not to NGOs but to free-lance practitioners in the wider context of the disappearance of organizational structures or units, which of itself calls for further empirical study from a political economy perspective. The dismantling of the World Bank's Development Communication Division (Enghel, 2013), the closure of Panos London (Panos London, 2012; Deane, 2012) ${ }^{11}$ and the paralysis of the Communication for Social Change Consortium (CFSC, 2014 ${ }^{12}$ ) in recent years speak of organizational spaces and resources once available being dismantled, but the reasons for such a shift remain unclear. The reader should note that, while I am not necessarily advocating for granting Northern based NGOs an exclusive or prevalent role in the mediation of development communication interventions (see e.g. White, 2004 for a critique of their limits), an institutional preference for free-lance practitioners vis-à-vis NGOs is likely to make for precarious conditions for implementation and hardly any accountability (Enghel, 2014).

The practice of development communication, generally presumed to be democratizing in line with normative ideals, has traditionally been structured by bilateral and multilat- 
eral development agencies through what I call the institutional project, which sets the 'rules of the game', giving shape to implementation, evaluation and the communication of results in line with its priorities and allocating funding accordingly ${ }^{13}$. Although research shows that privately funded aid is on the rise (e.g. Stoianova, 2012), bilateral and multilateral donors still are the most significant actors in the picture in terms of expenditure. Development communication initiatives deployed in the context of wider international development communication intervention are selected for implementation in line with foreign policy agendas (for an example see Enghel, 2014), and take place abroad, in countries other than those funding the initiatives ${ }^{14}$, producing specific types of proximity and distance through the mediation of international relationships. Despite much talk about 'partnership' (Erikson Baaz, 2005; Schech, 2014), the ability to initiate and terminate actions lies with the funders at the expense of the citizens named as beneficiaries of initiatives, at times bypassing the governance structures of recipient countries (including their media systems and local capacities).

\section{Development Communication under Present Conditions}

In recent years, media and information have become commodities crucial for the expansion of global capitalism (Schiller, 2007; Chakravartty \& Schiller, 2010), while the shape and strengths of a much-predicated global citizenship presumably in the making remain unclear (Sassen, 2008; Fraser, 2008). Inequality is mounting (Wilkinson and Pickett, 2010; Ortiz and Cummins, 2011), and development is increasingly managed by national states as a service delivery business subcontracted to the private sector (Anderson et. al., 2012). The privatization of development arguably weakens civil society, forecloses independent and critical research, and pushes decision-makers at national level to serve private agendas (Barkan, 2013; Wilkins and Enghel, 2013). This new institutional order in formation, well problematized by sociologist Saskia Sassen (2008), has a normative authority that comes from the world of private power yet installs itself in the public realm, emerging as public policy or public objectives. Particular institutional components of national states begin to function as the institutional home for the operation of powerful dynamics constitutive of global capital and its markets (including the liberalization of the telecommunications and media sectors; see Chakravartty \& Schiller, 2010), thus reorienting state agendas and policy work towards the requirements of the transnational economy. One of those dynamics is the fast digitization of a wide array of economic and political activities, accompanied by "purely technological readings of the technical capacities entailed by digitization" (Sassen, 2008: 329; see also Silverstone, 2007).

The adoption of selective business principles and practices among development providers in the context of a broad pro-privatization climate has had a number of negative cumulative effects (see Anderson et al., 2012 for a well-documented discussion). The number of development players has grown, leading to an increasingly "cluttered" landscape (Bellemare, 2014) and to a multiplicity of single-issue agendas, which compete with integrated approaches to justice (IDC, 2012). Moreover, the increasing visibility and influence of 'big philanthropy' subtracts attention from the persistence of the national as a material framing for citizenship (Sassen, 2008), as well as from the sustained, although changed, importance of national communicative spaces (Christensen, 2010). 
In parallel, strong discourses about the Internet's "built-in autonomy from state power and its capacity to enhance democracy from the bottom up via a strengthening of [...] access by civil society" (Sassen, 2008: 330) continue to distract attention from the fact that digital democracy is an overstated promise rather than a reality (Chakravartty \& Schiller, 2010; Fenton, 2011).

\section{Development Communication in the Context of Neoliberal Digital Capitalism}

A problematic relationship between globalization (Sassen, 2008), informationalized capitalism (Schiller, 2007) and development communication is acknowledged by scholars in discussions of development communication published in recent years (see Enghel, 2014 for details). References are made e.g. to the role that social movements and citizens' media may play in redressing the consequences of neoliberalism (White, 2004), to the unsolved social and geographical imbalances in 'the rise of the networked society' argued by sociologist Manuel Castells in the mid-nineties (Gumucio-Dagron and Tufte, 2006), to the advent of digital capitalism in the context of the neoliberal agenda and the globalization of poverty (Thomas, 2007), and to the potentially problematic consequences of favoring narrow visions of social change driven by commercial agendas and capitalist values (Wilkins, 2008; Wilkins and Enghel, 2013; Scott, 2014). Remarks are often times made from normative standpoints, i.e. derived from a concern with what the role of development communication is and should be, while in-depth attempts at explaining the influence of the neoliberal project (and of the commodification of media and information) as a key component of globalization on the practice and the project of international development communication remain, for the most part, a pending task within the literature.

This blind spot in theory-building is in turn reflected in empirical research. To give an example, more than $80 \%$ of the peer-reviewed academic articles on development communication published from 1997 to 2007 "made no mention of globalization", although more than 40\% focused on ICTs (Ogan et al, 2009: 660). While the research studies reviewed by Ogan et. al. (ibid) followed the practice through empirical studies, thus giving increased attention to projects incorporating ICTs, the ensuing analyses remained theoretically grounded in outdated explanatory principles drawn from the field's history. Alert to this problem, Chakravartty (2009) calls for critical attention to the renaissance seen by development communication in the twenty-first century, signaled by "an astonishing acceleration both in the scale of development projects based on information and communication technologies and in its symbolic significance in promising a painless transition to modernity" (ibid: 37 ).

Inasmuch as the media arguably play an increasingly pervasive role in the everyday life of citizens, and in the politics, the economies and the governance of most societies, the role of communication systems, industries and rationales in the neoliberal project merits critical scrutiny (Wilkins and Enghel, 2013; Scott, 2014). Given this complex scenario, what can a political economy approach to communication in development bring into an agenda for the field's future? 


\section{Looking for the Way Forward}

In 2003, diffusion and participation were considered the field's two dominant conceptual models (Morris, 2003) and the way forward for development communication was deemed to lie in establishing a new relationship between the two models by "theorizing across" (ibid: 243) and incorporating the best of both approaches (see also Roman, 2005 and Inagaki, 2007 for similar calls for coherence). Since then, suggestions for advancing the field of development communication have varied (see e.g. Shah, 2008 for his 'regions in protest' model; Greiner and Singhal, 2009 for 'invitational social change'; and Kim, 2005 for cross-fertilization between intercultural and development communication). Certain calls have insisted on the democratizing value of participatory approaches from a normative perspective (see e.g. Gumucio-Dagron and Tufte, 2006 and Dutta, 2011).

While in recent years scholars have raised calls for adopting a political economy approach in order to examine a variety of factors affecting the project and practice of development communication (Waisbord, 2008) and critically interrogate the status of the field under global and neoliberal conditions (Thomas, 2007; Wilkins, 2008; Chakravartty, 2009), these remain unheeded in empirical research. Singularly preoccupied with the subsidiary status of communication within the international aid system, and attentive to the materiality of politics, Waisbord (2008: 519) calls for "embracing an analytical perspective that examines organizational dynamics and professional micropolitics to assess how alternatives to the informational paradigm might be effectively institutionalized in development agencies" if communication is ever going to lead, rather than support, development programs. In pointing out the weak influence of theorization on the institutionalization of participatory development communication within the international aid system and arguing for empirical attention to the unstable conditions under which development communication is put into practice across organizations, Waisbord's suggested approach (ibid) pays due attention to processes as they unfold over time, and to ensuing issues of power, in line with my argument for a political economy of communication in development.

A concern with how to link development communication with globalization and informationalized capitalism is expressed by Chakravartty (2009), who calls for studies that "critically assess the new lexicon around technology and governance" and for ethnographies that pay attention not only to the possibilities of participatory approaches but also "offer meaningful critiques" of their limits. In what in my view may be seen as a productive contradiction among agendas that goes beyond a theoretical dilemma, Chakravartty (ibid: 38-39) argues for critical attention to the hyping up of social entrepreneurship as "the panacea to inequality in the global age", while from a more pragmatic and less critical perspective McAnany (2012) suggests that social entrepreneurship has lessons to offer.

\section{Why a Critical Political Economy Approach to Communication and Development?}

It is not possible to provide an overview of the political economy of communication - its characteristics, schools of thought, growth in recent years and current trends in research - here (see e.g. Mosco, 2009 and chapter 3 of Flew, 2007 for introductions; see also Chakravartty and Zhao, 2007 and Fuchs, 2014 for additional discussions). I must 
proceed to discuss how a political economy of communication in development would look like, and what its uses may be.

To begin with, a political economy approach to the study of development communication could be productive in four distinct ways (Mosco, 2009; Flew, 2007). First, as an alternative to a narrow focus on the effects of initiatives decontextualized from the sociopolitical circumstances of their implementation, it would give attention to the 'social totality', making it possible to identify and analyze the interconnections between the systems of economic, political and symbolic power at play in the practice and the project of development communication, and the ensuing synergies, rivalries, tensions and contradictions. Second, it would inform a future-oriented perspective grounded in an adequate understanding of recent history informed by the analysis of trends, including comparison over time and across actors and priorities. Third, it would illuminate the changing power balance -and forms of interaction- between the media and information industries on the one hand, and the funding and recipient governments on the other. This is particularly important when we consider for example that the Bill and Melinda Gates Foundation, a private entity created in 1994 with funds derived from the wealth accrued by Bill Gates as founder and chief executive of Microsoft, reports to the OECD since 2009 given its relevance as an 'investor' in global health ${ }^{15}$, while at the same time it is funding OECD work towards global policy in development data through a USD $2,000,000$ grant allocated in $2013^{16}$. The example suggests a correlation between the economic power derived by privileged individuals from the media industries and the ensuing possibility to influence international policy agendas through their philanthropic arms, which calls for further investigation. Fourth, a political economy approach to the study of communication in development would emphasize the analytical relevance of attending to praxis, i.e. to the relationship between academic research and practice, and the wider governance contexts which they seek influence (see Waisbord, 2008 for a discussion of the limited impact of academic work on the approaches favored by bilateral and multilateral agencies; see Quarry and Ramírez, 2009 and 2012, for a discussion of the limited impact of practitioners' views on the agendas of said agencies).

But there is one other way in which a political economy approach to the study of development communication would be analytically productive. Such an approach could of course involve mapping and analyzing the relevant structures in which development communication takes place - roughly, the bilateral and multilateral agencies that decide on priorities and fund it (but also the private philanthropic enterprises that do so), the intermediary organizations that implement it (be them non-governmental, business service, or free-lance endeavors), and the spaces that gather the target beneficiaries of choice in recipient countries (e.g. ordinary citizens in specific political jurisdictions or media workers in journalist unions or state broadcasters). Maps, however, should be considered temporary and therefore monitored regularly, since, as exemplified earlier in this article (see also Enghel, 2013; Waisbord, 2008), the international development cooperation structures in which priorities are decided, funding is allocated and the implementation of development communication initiatives is managed are constantly changing.

Given the changing quality of structures, analytical work should also focus on the study of processes (Mosco, 2009; Enghel, 2014). This could be done by e.g. adapting the conceptual framework put forward by Mosco (2009) for the political economy of communication at large, which foregrounds commodification, spatialization and structura- 
tion in order to characterize processes rather than simply identify relevant institutions. In Mosco's proposed framework, each of those three entry points highlights a question: commodification refers to how the human act of communication becomes a product produced for a profit; spatialization to what happens when communication goes global and businesses use it to create and manufacture their products worlwide; and structuration to how social relations are created through communication -mainly those organized around social class, gender and race, but also social movements and hegemony.

There are two significant dimensions in the relationship of commodification to communication (Mosco, 2009): that communication processes and technologies contribute to the general process of commodification in the economy as a whole; and that commodification processes at work in the society as a whole penetrate communication processes and institutions, in such a way that improvements and contradictions in the societal commodification process influence communication as a social practice. Due to the emphasis on structures and objects over processes and relations typical of traditional political economy studies of communication, commodification has not received substantial explicit treatment, and when treated the focus has been more on media content and less on media audiences even if the production of audiences (as well as of labor, also neglected) is central to the commodification process. As commodification is increasingly externalized, i.e. extended to areas historically left outside the process or only lightly affected by it, "institutional areas that were once resources available to all irrespective of market power" (Mosco, 2009; see also Garnham, 1999) shift towards approaches in which access - e.g. to mobile phones or to Internet connectivity, in the case of development communication intervention- becomes dependent on one's ability to pay.

Adapting the framework to development communication scholarship, commodification could be understood to refer to how the human act of communication becomes a result produced for a gain through a specific type of needs-based service delivery (see e.g. Quarry and Ramírez, 2012; Anderson et al, 2012); spatialization to what happens when global communication resources are used by bilateral and multilateral agencies to mediate intervention at a distance and manage international relationships in the process (Enghel, 2014); and structuration to how social relations are created through communication, particularly those derived from the governance of unequal conditions via a structure that combines competing national and international scales. Attention to structuration would bring into view the connection between the fate of citizens addressed by international interventions in recipient countries and the related (success) stories told to tax-paying citizens in funding countries (Wilkins and Enghel, 2013; Enghel, 2014; see also Fraser, 2008; Silverstone, 2004 and 2005; García Canclini, 2006).

A political economy approach to development communication moreover brings back into view the role of national states in the deployment of interventions. Attention to national states and their respective structures of governance is important in order to establish whether interstate coordination among funders and recipients is present or absent, and thus clarify which avenues for raising claims and for seeking accountability may be available (or lacking) for the citizens tackled through specific development communication interventions (Enghel, 2014). Moreover, attention to national states as one of the three relevant macro-scale actors in the 'game' of development communication -together with the private sector, be it the market or its philanthropic arm, and 
citizens- makes it possible to begin to identify how the processes of commercialization, liberalization, privatization and transnationalization of communication systems and networks that continue to take place under neoliberal conditions (Schiller, 2007; Sassen, 2008; Mosco, 2009;) manifest in the specifics of the practice and project.

\section{Querying Development Communication as a Three-dimensional Object of Analysis}

I have exemplified earlier in the article a number of questions that could be productively addressed through a political economy approach to communication in development. If we were to focus primarily on the academic dimension, additional enquiries could look into e.g. unpacking the vicious circle of decision-makers asking academics for proof that development communication works (see e.g. Lennie \& Tacchi, 2013) or identifying the reasons for the absence of sustained, substantial dialogue among researchers, practitioners and decision-makers (see Servaes, 2007; Waisbord, 2010). Moreover, the presence or absence of a correlation between the specialized graduate education and training on offer and the professional placements at the level of the practice and institutional project could be explored. The absence of open-access searchable knowledge repositories based at universities or other public institutions committed to promoting the productive use of scholarship could also be investigated in connection with the existence of webbased online networks that have grown to play a significant role in the dissemination of information relevant to the field (such as The Communication Initiative or The C4D Network $^{17}$ ) but struggle for economic sustainability.

If we were to focus primarily on the practice dimension, additional enquiries could look into e.g. the reasons for (and consequences of) the scarcity of codes of practice, ethical guidelines and accountability mechanisms for practitioners at varying scales, including individual free-lancers, NGOs and international civil servants. More widely, studies that investigate the workplaces and working conditions of the field's 'human resources' would illuminate structural conditions and their impact.

If we were to focus primarily on the institutional project dimension, additional enquiries could look into e.g. the actual ways in which bilateral, multilateral and Northernbased non-governmental organizations resort to development communication in order to fulfil their agendas beyond normative ideals, thus illuminating a number of important aspects of the project, including (but not limited to) change and continuity in the matrix of core institutional players influential in the field, rationales for decision-making, overlap between 'doing good' and 'looking good', and tensions and contradictions derived from understanding communication as a right or as a commodity.

\section{Final Considerations}

In standard approaches to development communication, citizens on both ends of the funder-recipient equation tend to be disregarded. In so called 'developed countries', they are prompted to consume as a way to show compassion (see e.g. Richey and Ponte, 2011), and in the process offered simplistic accounts of the complex causes of poverty and inequality under global conditions. In so called 'developing countries', they are treated as the end that justifies the means, while the distance between them and donors 
becomes increasingly intermediated by profit-making private actors and keeps growing (see e.g. Anderson et. al., 2012; Enghel, 2014).

A 'politics of the possible' requires that scholars take responsibility for critically understanding the present of the development communication field not merely in normative or instrumental terms, but also as regards material conditions and power inequalities. It also requires empirical and theory-building work that seeks to deepen and strengthen our understanding of the relationship between communication, media, citizenship and social change in the context of neoliberal globalization. A political economy approach to communication in development would allow a productive engagement with the challenge.

\section{Notes}

1. Development is understood here as "the organized intervention in collective affairs according to a standard of improvement" (Nederveen Pieterse, 2010: 3). What constitutes improvement -and appropriate intervention- is a matter of contestation and negotiation in pertinent international arenas.

2. After two years of falling aid budgets in 2011 and 2012 in the context of tightening budgets after the 2007-2008 global financial crisis, levels rebounded in 2013. See http:/www.oecd.org/development/ aidtopoorcountriesslipsfurtherasgovernmentstightenbudgets.htm [accessed 22 October 2013] and http:// www.oecd.org/newsroom/aid-to-developing-countries-rebounds-in-2013-to-reach-an-all-time-high.htm [accessed 22 September 2014].

3. This denomination is the one adopted by the International Encyclopedia of Communication in 2008 (listed in the references as Wilkins, 2008).

4. For an earlier discussion of this problem see Servaes (1996).

5. While development communication is not necessarily limited to institutionally driven top-down interventions, and participatory and citizen-led instances exist, in this article I focus on the latter rather than the former attentive to the fact that agency cannot be adequately analyzed in the absence of structures (Mosco, 2009).

6. See http://www.oecd.org/about/history/ [accessed 23 September 2014].

7. See da Costa (2009) for the distinction between communication about and for results.

8. According to an unpublished study commissioned by the OECD (Zimmerman, 2007, quoted in da Costa, 2009), approximately one-third of OECD countries integrated communication in development programmes or projects by 2009 , although half of those that had not yet moved in that direction spoke of planning to do so in the near future. What percentage of projects and programmes integrate communication is unclear. Only $10 \%$ of those donors integrating communication in development programmes or projects had a formal communication strategy.

9. The studies reviewed are: Morris (2003); Shah (2007); Inagaki (2007); Ogan et al. (2009); and Skuse et al (2013).

10. See http://www.unicef.org/cbsc/ [accessed 16 July 2014] and http://www.fao.org/communication-for-development/en/ [accessed 12 November 2014]

11. See http://panos.org.uk/about-us/press-releases/ and http://www.comminit.com/policy-blogs/content/ memoriam-panos-london [accessed 23 September 2014].

12. See http://www.communicationforsocialchange.org/news?articleid=86 [accessed 23 September 2014].

13. See e.g. how the World Bank conceptualizes the role of ICTs as a driver of women's agency, voice and participation in Klugman et al (2014).

14. Although a few examples of indigenous development communication initiatives exist at the national level, led by a government agency (such as e.g. the Secretary of Information and Communication for Development created by the government of Paraguay in 2008) or civil society organization (such as e.g. the association of social communicators Calandria, created in Perú in 1983), the number is so small that they must be considered the exception to the rule.

15. See e.g. http://www.oecd.org/dac/47539494.pdf [accessed 23 september 2014].

16. See http://www.gatesfoundation.org/How-We-Work/Quick-Links/Grants-Database/Grants/2013/11/ OPP1095783 [accessed 23 september 2014]

17. See http://www.comminit.com/global/spaces-frontpage and http://c4dnetwork.ning.com/ [accessed 29 September 2014]. 


\section{References}

Alfaro, Rosa María (2012) is it possible to generate development starting from communication? In Nordicom Review (33), 121-134.

Anderson, M., Brown, D., \& Jean, I. (2012). Time to listen: hearing people on the receiving end of international end. Cambridge: CDA Collaborative Learning Projects.

Barkan, J. (2013). Plutocrats at Work: How Big Philanthropy Undermines Democracy. Social Research: An International Quarterly of the Social Sciences.

Bellemare, M. (2014). Development bloat: how development hurts the world's poor. Foreign Affairs. Retrieved from http://www.foreignaffairs.com/articles/140624/marc-f-bellemare/development-bloat [accessed 12 November 2014]

Chakravartty, P. (2009). Modernization Redux? Cultural Studies \& Development. Television \& New Media, (10) 1, 37-39.

Chakravartty, P. \& Zao, Y. (2008). Introduction: Toward a Transcultural Political Economy of Global Communication in Chakravartty, P. \& Zao, Y. (eds.) Global communications: Toward a transcultural political economy. Lanham: Rowman \& Littlefield Publishers.

Chakravartty, P., \& Schiller, D. (2010). Neoliberal Newspeak and Digital Capitalism in Crisis. International Journal of Communication, (4) 670-692.

Christensen, M. (2010). Notes on the public sphere on a national and post-national axis: Journalism and freedom of expression in Turkey. Global Media \& Communication, (6) 2, 177-197

da Costa, P. (2009). Study on Communicating Development Results. Retrieved from: http://www.oecd.org/ dev/devcom/44836250.pdf [accessed 6 March 2013]

Davies, Robin (2013) Felled before forty: the once and future AusAID. In DevPolicy Blog. Retrieved from http://devpolicy.org/felled-before-forty-the-once-and-future-ausaid/ [accessed 11 November 2014]

Deane, J. (2012) In memoriam: Panos London. Retrieved from: http://www.comminit.com/global/content/ memoriam-panos-london [accessed 11 November 2014]

Dubet, F. (2011). Repensar la justicia social. Buenos Aires: Siglo XXI.

Dutta, M. (2011). Communicating social change: structure, culture and agency. London and New York: Routledge.

Enghel, F. (2013). Communication, development and social change: future alternatives. In: Wilkins, K., Straubhaar, J. \& Kumar, S. Global communication / New agendas in communication. New York: Routledge.

Enghel, F. (2013). Desiguales, diferentes y desconectados: la comunicación para el desarrollo como interrogante. In C. Castillo Rocha, D. Murillo Licea, \& R. Quiroz Carranza, Comunicación y desarrollo en la agenda latinoamericana del siglo XXI. Tomo 1: Fundamentos teórico-filosóficos. Mérida: Universidad Autónoma de Yucatán.

Enghel, F. (2014). Video letters, mediation and (proper) distance: A qualitative study of international development communication in practice. Karlstad: Karlstad University Studies.

Erikson Baaz, M. (2005) The paternalism of partnership: A Postcolonial Reading of Identity in Development Aid. London: Zed Books.

Evans, Alex (2013) Delivering the post-2015 development agenda: Options for a new global partnership. New York: New York University/Center for International Cooperation.

Fenton, N. (2011) Multiplicity, autonomy, new media, and the networked politics of new social movements. In: Dahlberg L. \& Phelan S. (eds.) Discourse Theory and Critical Media Politics. New York: Palgrave Macmillan, 178-200.

Flew, T. (2007) Understanding global media. New York: Palgrave Macmillan.

Fraser, N. (2008). Scales of Justice / Reimagining Political Space in a Globalized World. Cambridge: Polity Press.

Fuchs, C. (2014) WikiLeaks and the Critique of the Political Economy. In International Journal of Communication (8).

García Canclini, N. (2006). Diferentes, desiguales y desconectados: mapas de la interculturalidad. Barcelona: Gedisa.

Garnham, N. (1999). Amartya Sen's “capabilities" approach to the evaluation of welfare: its application to communications. In Calabrese, A. \& Burgelman, J. Communication, citizenship, and social policy: rethinking the limits of the welfare state. Lanham: Rowman \& Littlefield.

Greiner, K., \& Singhal, A. (2009). Communication and invitational social change. Journal of Development Communication, (20) 2, 31-44.

Gumucio-Dagron, A. \& Tufte, T. (Eds.) (2006) Communication for Social Change Anthology: Historical and Contemporary Readings. New Jersey: CFSC.

Hamelink, C., \& Hoffmann, J. (2008). The state of the right to communicate. Global Media Journal (7), 13. 
Hammersley, M., \& Atkinson, P. (2007). Ethnography: principles in practice (3rd edition). London and New York: Routledge.

IDC (2012). Private foundations: thirteenth report of session 2010-12. London: House of Commons.

Inagaki, N. (2007). Communicating the impact of communication for development: recent trends in empirical research. Washington: The World Bank.

Jacobson, T., \& Storey, D. (2004). Development communication and participation: applying Habermas to a case study of population programs in Nepal. Communication Theory, (14) 2, 99-121.

Kim, Y.Y. (2005). Inquiry in intercultural and development communication. Journal of Communication, (55) 3, 554-557.

Kincaid, D., \& Figueroa, M. (2009). Communication for participatory development: dialogue, action and change. In Frey, L. \& Cissna, K. Handbook of Applied Communication Research (ss. 506-531). New York: Routledge.

Klugman, J.; Hanmer, L.; Twigg, S.; Hasan, T.; McCleary-Sills, J.; Santamaria, J. (2014). Voice and Agency : Empowering Women and Girls for Shared Prosperity. Washington, DC: World Bank Group.

Lennie, J., \& Tacchi, J. (2013). Evaluating Communication for Development: A Framework for Social Change. Oxon: Routledge.

Manyozo, L. (2006). Manifesto for development communication: Nora Quebral and the Los Baños School of Communication. Asian Journal of Communication, (16) 1, 79-99.

Manyozo, L. (2012). Media, communication and development: three approaches. New Delhi: SAGE.

McAnany, E. (2010). Communication for development and social change: new millennium. Communication Research Trends, (29) 3, 3-17.

McAnany, E. (2012). Saving the world: a brief history of communication for development and social change. Champaign: University of Illinois Press.

McPhail, T. (2009). Development communication: reframing the role of the media. Oxford: Blackwell Publishing.

Morris, N. (2003). A comparative analysis of the diffusion and participatory models in development communication. Communication Theory, (13) 2, 225-248.

Mosco, V. (2009). The political economy of communication. London: SAGE.

Nederveen Pieterse, J. (2010). Development theory: deconstructions/reconstructions (second edition). London: SAGE.

Ogan, C., \& al, e. (2009). Development communication: the state of research in an era of ICTs and globalization. The International Communication Gazette, (71) 8, 655-670.

Ortiz, I. \& Cummins, M. (2011). Global inequality: beyond the bottom billion - A rapid review of income distribution in 141 countries. New York: UNICEF.

Quarry, W. \& Ramírez, R. (2009) Communication for another development: Listening before telling. London: Zed Books.

Quarry, W. \& Ramírez, R. (2012) The limits of communication: The gnat on the elephant. In Nordicom Review (33), 121-134.

Ramafoko, L., Andersson, G. \& Weiner, R. (2012) Reality television for community development: The Kwanda initiative in South Africa. In Nordicom Review (33), 149-162

Richey, L. \& Ponte, S. (2011) Brand Aid. Shopping Well to Save the World. Minneapolis: University of Minnesotta Press.

Roman, R. (2005). The place of theory in development communication: retrospect and prospects. Communication yearbook (29), 311-331.

Sassen, S. (2008). Territory, authority, rights: from medieval to global assemblages. New Jersey: Princeton UNiversity Press.

Schech, S. (2014) Can development be a partnership? Panel presentation delivered at the Voice \& Matter Conference, Malmö University.

Schiller, D. (2007). How to think about information. Champaign: University of Illinois Press.

Scott, M. (2014). Media development. London: Zed Books.

Servaes, J. (1996). Linking Theoretical Perspectives to Policy. In Servaes, J., Jacobson, T. \& White, S. Participatory communication for social change. New Delhi: SAGE.

Servaes, J. (2005). Mapping the new field of communication for development and social change. In Social change in the 21 st century Conference. Queensland: Queensland University of Technology.

Servaes, J. (2007). Communication for Development: Making a Difference, a WCCD background study. In Servaes, J. (ed.) World Congress on Communication for Development: Lessons, Challenges and the Way Forward. Washington: The World Bank.

Servaes, J. (2011). Communication for sustainable development: indicators for impact assessment in USAID project "Educational reform in the classroom in Guatemala". Journal of Latin American Communication Research, (2) 2. 
Shah, H. (2007). Meta-research of development communication studies. In Glocal Times \# 13.

Shah, H. (2008) Communication and marginal sites: the Chipko movement and the dominant paradigm of development communication. Asian Journal of Communication, (18) 1, 32-46.

Silverstone, R. (1999). Why study the media? London: SAGE.

Silverstone, R. (2004). Proper Distance: Towards an ethics for cyberspace. In Liestil, G., Morrison, A. \& Rasmussen, T. Digital Media Revisited: Theoretical and Conceptual Innovations in Digital Domains. Massachussets: MIT.

Silverstone, R. (2007). Media and morality: on the rise of the mediapolis. Cambridge: Polity Press.

Skuse, A., Rodger, D., Power, G., Mbus, D., \& Brimacombe, T. (2013). Communication for Development Interventions in Fragile States: A Systematic Review. Adelaide: JBI Database of Systematic Reviews \& Implementation Reports.

Stoianova, V. (2012) Private funding: An emerging trend in humanitarian donorship. Somerset: Global Humanitarian Assistance

Thomas, P. (2007). Communication and social change. In Srampickal, J. \& Arul, A. Understanding development communication. Delhi: Media House.

Tufte, T. (2005). Communication for social change: struggles for visibility and voice, culture and diversity. Paper presented at the International Communication Association Conference.

Tufte, T. (2014) Civil society sphericules: Emerging communication platforms for civic engagement in Tanzania in Ethnography (15) 1, 32-50.

UNICEF, \& CI. (2012). Towards a Global C4D Association: Report on an exploratory consultation. New York: UNICEF.

Waisbord, S. (2008). The institutional challenges of participatory communication in international aid. Social Identities: Journal for the Study of Race, Nation and Culture, (14) 4 505-522.

White, R. (2004). Is empowerment the answer? Current theory and research on development communication. Gazette, (66) 1, 7-24.

Wilkins, K. (2009). What's in a name? Problematizing communication's shift from development to social change. Glocal Times \# 13.

Wilkins, K. (2008). Development Communication. In Donsbach, W. (ed.) The International Encyclopedia of Communication. Blackwell Publishing.

Wilkins, K., \& Enghel, F. (2013). The privatization of development through global communication industries: Living Proof? Media, Culture \& Society, (35) 2, 165-181.

Wilkinson, R., \& Pickett, K. (2010). The spirit level: why equality is better for everyone. London: Penguin. Williams, R. (1983). Keywords: a vocabulary of society and culture. New York: Oxford University Press. 